\title{
Resisting Timber Joint Performance of Karo Wooden Building
}

\author{
Khairussa'diah and Yulianto P. Prihatmaji
}

\begin{abstract}
Batak Karo is one of the ethnic group that exists in North Sumatra. Wooden house of Batak Karo called with Siwaluh Jabu. This wooden house has a structure system of pillars on top of stone foundations. This type of foundation is able to improve the performance of the overall structure due to lateral style caused by the earthquake. This research was conducted to know the behaviour of the structure of a wooden Batak Karo home especially the restoration of wooden style joints by comparing the results of a laboratory test, numerical analysis and analysis with SAP2000. Experimental testing in the lab do the test objects as much as 3 pieces. Testing by giving a cyclic load with a capacity of 10 tons in each of the test object to damaged object. Then conduct an evaluation the behavior of the structure consist of failure modes and moment-rotational angle relationship. After the experimental test was completed, the analysis continued with validate test results with laboratory of numerical analysis. Then conducted an analysis of the power structure by using SAP2000 program to know the power of elements against the maximum tension. The analysis conducted on the overall structure of the system and the structure of mast above the foundation stone. The program was conducted with input data: the work load, etc. As the output from these programs is the element force, etc. The final results of this program are the weaknesses and advantages of structural system observed from wooden Batak Karo.
\end{abstract}

Keywords: Karo wooden structure, siwaluh jabu, timber joint, resisting performance, restoration.

\section{Introduction}

Karo tribe is one of the tribes living in the Highlands Karo, North Sumatra, Indonesia. Karo tribe has been one of district names where they lived (Karo highlands) is Karo. This tribe has their own language called Bahasa Karo and Karo script. Karo considered as part of tribal kinship Batak Karo tribe but lot of people assume that they were not part of a kinship Batak, but Karo is an independent tribe.

Wooden house of Karo known as Siwaluh Jabu. Nowadays its existence has been difficult to found. In 2011 Lingga village only four houses left, but due the earthquake that occurred a few years ago, two of them are collapsed and could not be occupied again (Prihatmaji and Widodo 2015). Siwaluh Jabu is very famous with the beauty of architecture which is typical, stout and sturdy and decorated with philosophical values ornaments. Form, function and meaning from Siwaluh Jabu illustrate the close relationship between human each other and also with natural environment. Selection of materials for Siwaluh Jabu and the construction process without the use of nails, iron or wire binding, but using pegs and rope fibers adds to the uniqueness of Siwaluh Jabu (Sembiring 2010).

Based on the results of survey we know that the main structure of this wooden house using several types of wood which are dustpan, ingul and icap wood. Siwaluh Jabu made based on knowledge from generation to generation. Although the ancient times there has been no theory of the building structure, our ancestors can create the structure that does not collapse during an earthquake. For example Omo Hada house located in Nias, North Sumatra, Rumah Gorga in Toba, North Sumatera, Tongkonan in Toraja, South Sulawesi and Uma Lengge in Mbawa, Nusa
Tenggara Barat. All of those Indonesian wooden wooden house using pedestals/ rock as a foundation, pillars only placed on pedestals/ stones without using a special joint, it has been proven (Nurdiah 2011), Omo Hada wooden home when the 8.7 scale Richter Nias earthquake (2005) did not run into structural collapse (Pranata and William 2013; Pudjisuryadi et al. 2007).

Pillars resting on a stone serves as base isolation in a wooden house. This system is called base isolation because the poles are not contact with the ground directly, but rests on a rock. As a result, these wooden houses can move from its original location when receive the lateral seismic loads. Moreover, it can cause vibration damping effect of the earthquake (Pudjisuryadi et al. 2007).

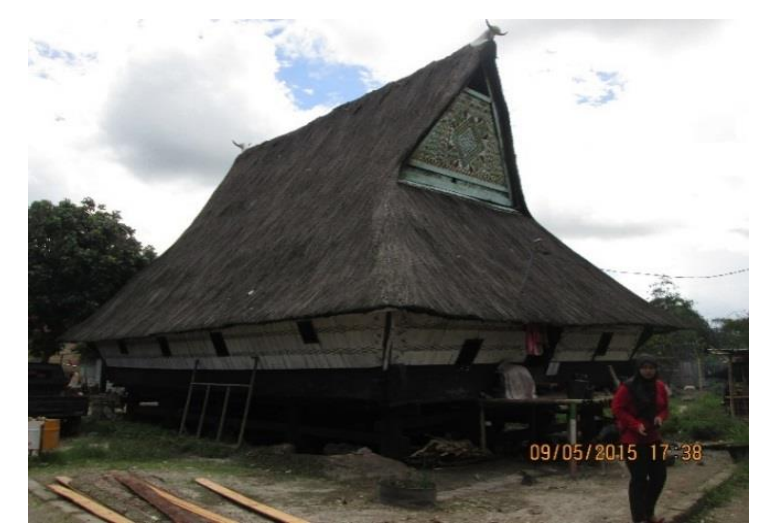

Figure 1. Wooden house Siwaluh Jabu of Karo Batak tribe (Prihatmaji and Widodo 2015). 
The purpose of this study is to discuss the behavior of the structural system of wooden wooden house Batak Karo due to gravity load and lateral load. Building structures and wooden material data become components of columns, beams, roof and floor boards drawn from the survey results directly.

Gravity load includes the weight of its own buildings, dead load and live load. Lateral load is based on seismic Indonesian earthquake rules of ISO 1726-2012 where for North Sumatra, the type of soil is assumed to normal type of soil which had risk buildings category IV and earthquake primary factor (le) 1.5 (ISO 1726-2012). Structure analysis of lateral loads using software SAP2000. Recording data is used seismic record of North Sumatra earthquake which intensity scaled to the maximum amplitude of ground acceleration (Ao) (ANSS 2015) on spectrum response curve of ISO 03-1726-2002 when T = 0 .

\section{Materials and Methods}

\section{Orthotropis Properties of Wood}

Wood has three axes of symmetry which intersect perpendicular due to the composition of the wood so that often referred to orthotropis properties. The third axis of symmetry is "longitudinal axis (extending the fiber)", "radial axis (perpendicular to growing circle)" and "tangential axis (alluded to growing circle)" (Mardikanto et al. 2015).

These three axis influenced by the orientation of the fiber structure, the cell radius (ray cell) as well as other wood-forming element (cell fibers, trakeida cells, parenchymal cells). The amount of wood stiffness and elasticity properties is different depending on the direction of the axis. In general, difference of these properties is determined by the fiber longitudinal direction (axial) and the perpendicular fibers (transverse) (Mardikanto et al. 2015). Difference in the properties of radial and tangential direction actually exist, but this difference usually very small and often overlooked.

\section{Mechanical Properties of Wood}

Material property data for mechanical properties of wood, using type of wood used Ulin (Eusideroxylon zwageri) with a specific gravity is 1.04 (PTHH 2005). In the properties of wood mechanical properties database, namely Atlas Wood Indonesia (PTHH 2005) of compressive strength parallel to Ulin amounted to $71.96 \mathrm{MPa}$, while the compressive strength perpendicular has been no reference. Ulin wood bending strength is equal to $109.12 \mathrm{MPa}$ (proportional limit load) and amounted to $140.29 \mathrm{MPa}$ (ultimate limit load / broken) (PTHH 2005). Ulin tensile strength is of $2.62 \mathrm{MPa}$ (radial) and amounted to $6.19 \mathrm{MPa}$ (tangential) (PTHH 2005).

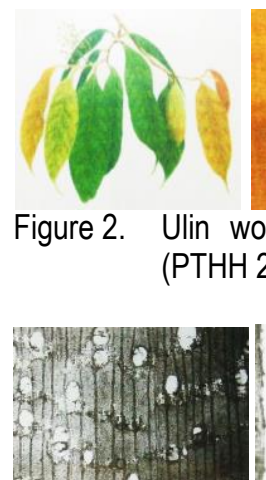

(a)

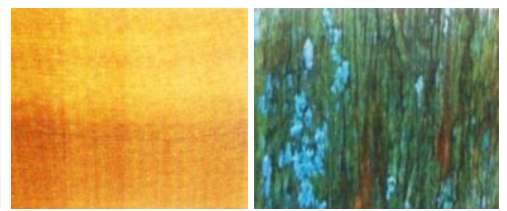

in wood (Eusideroxylon Zwageri T. Et. B) PTHH 2005)

Figure 3. Transverse surface (a), radial surface (b) and tangesial surfae (c) of Ulin wood (PTHH 2005).

\section{Historical Events of North Sumatra Quake}

Historical events of North Sumatra quake can be seen in Table 1 below.

Table 1. Historical earthquakes North Sumatra.

\begin{tabular}{cccrc}
\hline Year & Latitude & Longitude & \multicolumn{1}{c}{ Depth } & Magnitude \\
\hline 1972 & 3.274 & 98.522 & 124.00 & 5.30 \\
1974 & 2.829 & 98.975 & 33.00 & 5.00 \\
1976 & 3.166 & 99.015 & 180.00 & 5.60 \\
1989 & 2.845 & 99.127 & 187.30 & 5.20 \\
1990 & 3.322 & 98.401 & 144.90 & 5.10 \\
1996 & 3.445 & 97.943 & 33.00 & 6.30 \\
2001 & 3.718 & 97.794 & 139.10 & 5.10 \\
2005 & 2.836 & 98.758 & 30.00 & 5.20 \\
2006 & 3.390 & 99.079 & 204.00 & 6.30 \\
2009 & 2.800 & 99.086 & 174.80 & 5.10 \\
2014 & 2.835 & 99.071 & 170.89 & 5.60
\end{tabular}

Source: ANSS Composite Catalog Search (ANSS 2015).

Earthquake loading used in SAP2000 analysis using equivalent static seismic based UBC97. Because this rule become the basis of SNI 03-1726-2002 so that almost all of the input parameters are same so that the work of modeling the structure of Karo wooden house will be much easier.

\section{Analysis of the Structural Strength from the Program SAP2000}

SAP2000 program will help analyze the strength of the structural elements to the maximum voltage that occurs (Satyarno et al. 2012), so that it can be known weaknesses and strengths of the system structure of wooden Batak Karo house. 


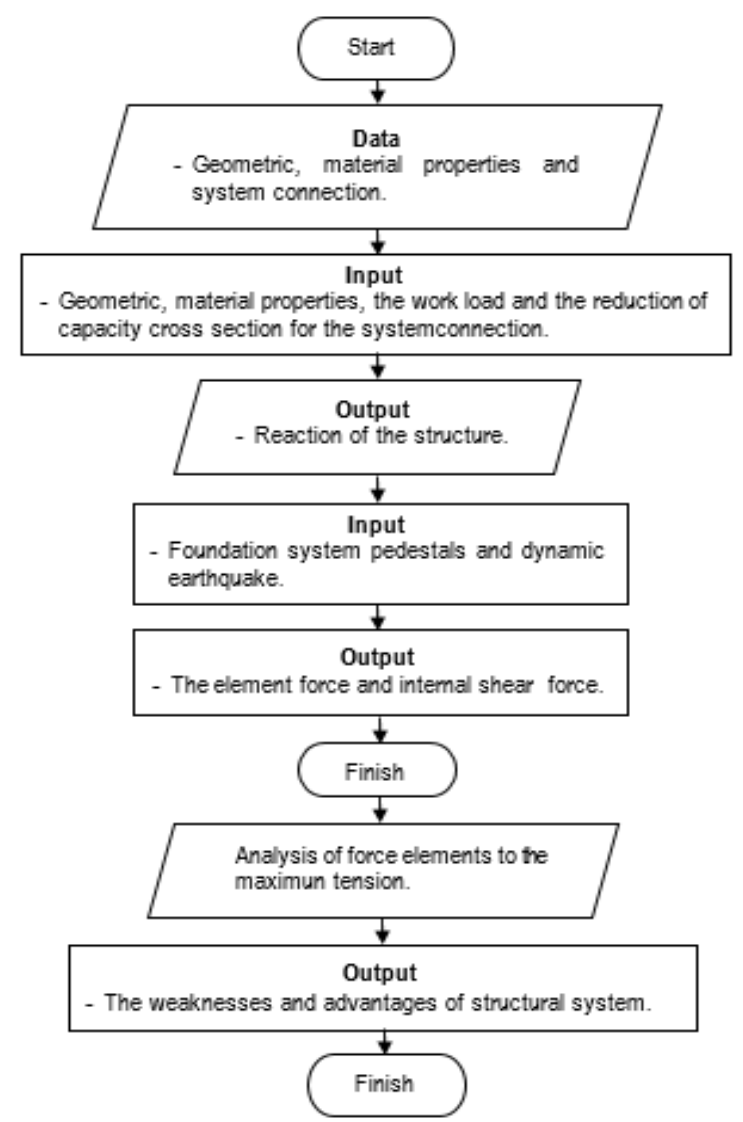

Figure 4. Analysis of the structural strength from the program SAP2000.

\section{Results and Discussion}

\section{Structures Data and Modelling of Structures}

The complete structure data taken from result of field survey on May-June 2015. The main column using crosssectional shape of a circle with a diameter of $340 \mathrm{~mm}$, the supporting pillar diameter of $300 \mathrm{~mm}$. Main beam from wood with a cross section size $100 \times 150 \mathrm{~mm}$ and $100 \times 120 \mathrm{~mm}$. Trunks for roof frame with a size of $140 \times 150 \mathrm{~mm}$ and $90 \times 100 \mathrm{~mm}$ as shown in Table 2 below.

Table 2. Data structure Karo wooden home.

\begin{tabular}{ccccc}
\hline House & $\begin{array}{c}\text { Main } \\
\text { pillar } \\
(\mathrm{mm})\end{array}$ & $\begin{array}{c}\text { Supporting } \\
\text { pillar }(\mathrm{mm})\end{array}$ & $\begin{array}{c}\text { Main } \\
\text { beams } \\
(\mathrm{mm})\end{array}$ & $\begin{array}{c}\text { Cross- } \\
\text { section } \\
\text { roof } \\
(\mathrm{mm})\end{array}$ \\
\hline $\begin{array}{c}\text { Batak } \\
\text { Karo }\end{array}$ & $\$ 340$ & $\$ 300$ & $\begin{array}{c}100 \times 150 \\
100 \times 120\end{array}$ & $\begin{array}{c}140 \times 150 \\
90 \times 100\end{array}$ \\
\hline
\end{tabular}

Wood material property data used in the modeling of the structure has been described previously in the Reader Review. The results of modeling the structure shown in Fig. 5.

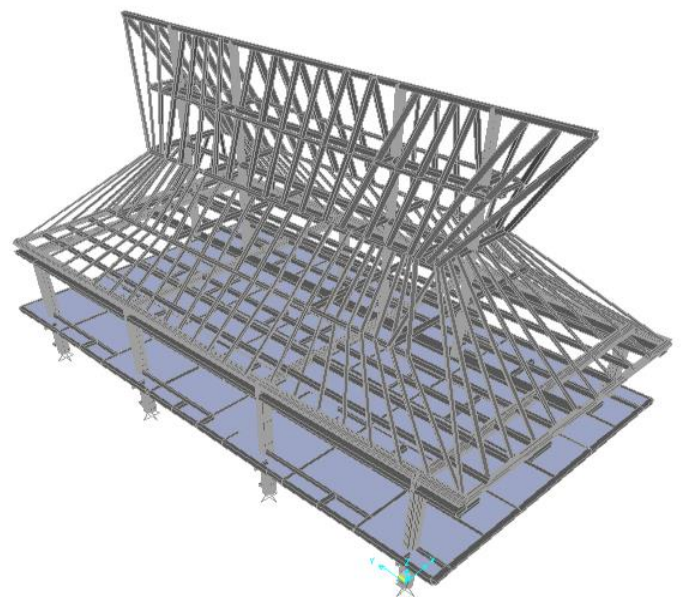

Figure 5. Result of 3D structure modeling for wooden house Karo.

In this study, the live load used is equal to $65 \mathrm{~kg} / \mathrm{m}^{2}$ and dead load at $6.5 \mathrm{~kg} / \mathrm{m}^{2}$. Earthquake loads used are seismic scaled load intensity of the maximum amplitude of ground acceleration $\left(A_{0}\right)$ on spectrum response curve ISO 1726-2012 when $T=0$ is equal to 0.28 .

Combination of loading that used are:
(a) $1.4 \mathrm{DL}$
(b) $1.2 \mathrm{DL}+1.6 \mathrm{LL}$
(c) $1,3042 \mathrm{DL}+0.5 \mathrm{LL} \pm \mathrm{E}$

where $\mathrm{DL}$ is dead loads, $\mathrm{LL}$ is the live load, and $\mathrm{E}$ is the earthquake load.

The simulation results from the software SAP2000 more shown in Fig. 6 is a deformation pattern of the structure due to simulated earthquake load, and Fig. 7 (normal force/ axial happened to the pole) and Fig. 8 (bending moments that occur in the beam) where the result is taken as a result of the maximum load combinations.

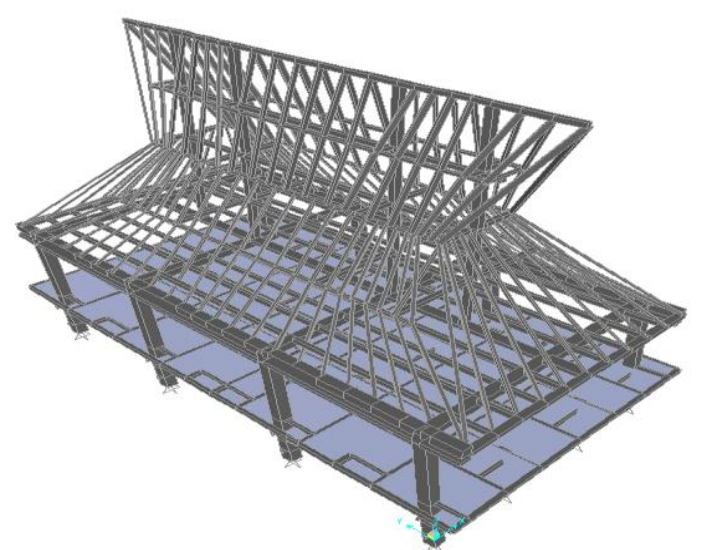

Figure 6. The pattern deformation simulation model of the structure due to earthquake load. 
From Fig. 6 , it can be seen that the simulation show the deformation that occurs in all poles still comply with the limits factored load combinations and load intellectually based ISO 1726-2012, so that the structure still meet the security criteria.

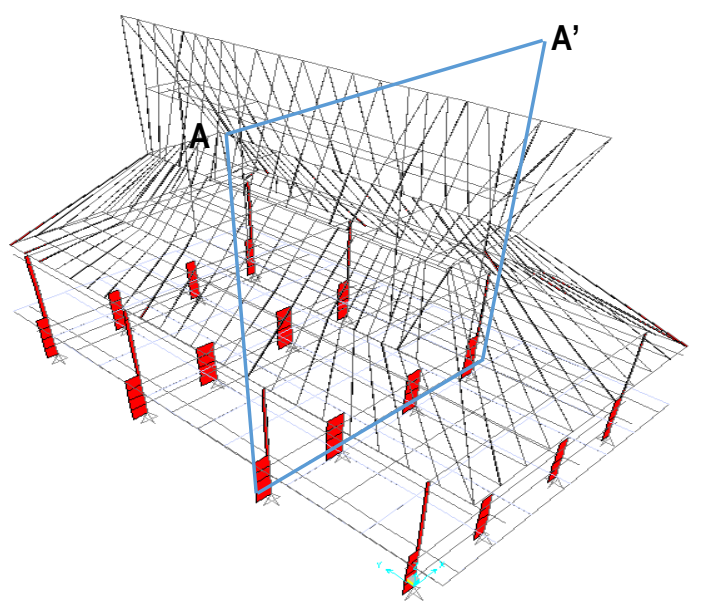

(a)

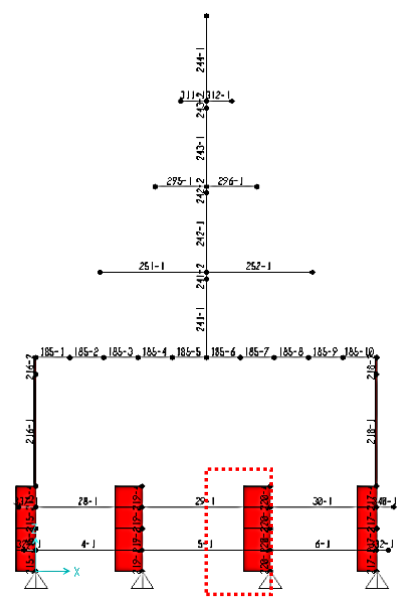

(b)

Figure 7. Axsonometry drawing (a), and section A-A' drawing.

The axial forces that occur in the column is $\mathrm{N}$, then the compressive strength in the column can be calculated by Equation (1) below.

$$
\sigma_{C}=\frac{P}{A}
$$

where ${ }^{\sigma_{C}}$ is the compressive strength of the column, $P$ is the axial force in the column, Aa is the column crosssectional.

$$
\sigma_{c}=\frac{P}{A}=\frac{631219,05}{\frac{1}{4} \times 1 \times \times 340^{2}}=6,952 \mathrm{MPa}<F_{e}=71,96 \mathrm{MPa}
$$

From Fig. 7, it can be seen that the simulation shows that compressive strength occurs in the column is still smaller than the compressive strength of wood is Fc of $65.24 \mathrm{MPa}$, so that the column is still in robust condition.

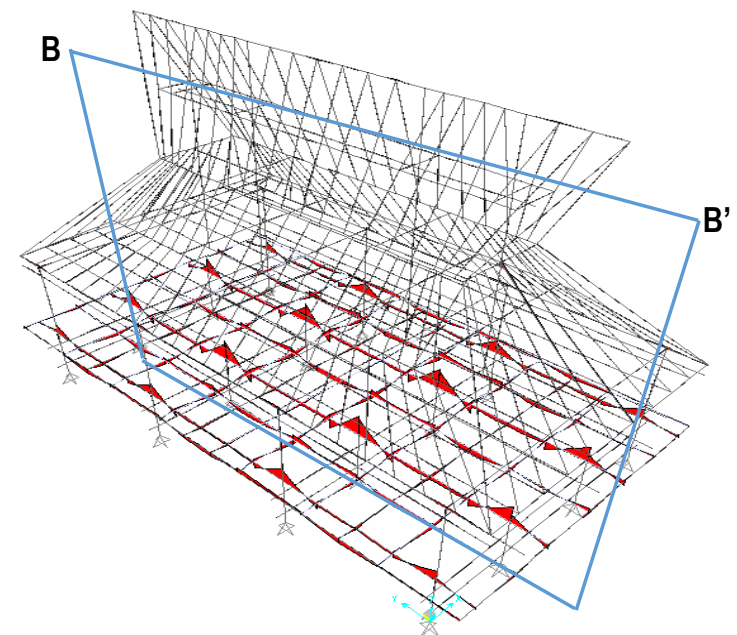

(a)

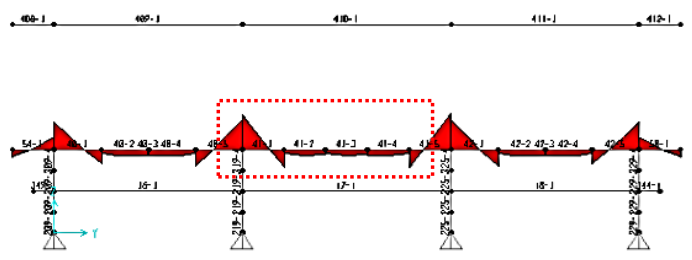

(b)

Figure 8. Axsonometry drawing (a), and section B-B' drawing.

The amount of bending strength that occurs can be calculated using Equation (2) below.

$$
\sigma_{b}=\frac{M}{I}
$$

where ${ }^{\sigma_{b}}$ is the beam flexural strength, $M$ is the bending moment on the beam, $y$ is the distance from the beam weight to the outer edge of the fiber, and $I$ is inertia moment of the beam.

$$
\sigma_{\mathrm{b}}=\frac{\mathrm{M}}{\mathrm{I}}=\frac{212041624}{\frac{1}{12} \times 170 \times 65^{\mathrm{x}}}=54,502 \mathrm{MPa}<F_{\mathrm{b}}=109,19 \mathrm{MPa}
$$

From Fig. 8, it can be seen that the magnitude of the flexural strength that occurs is still not exceed the limits $\mathrm{Fb}$ flexural strength of $109.19 \mathrm{MPa}$. Recapitulation of Batak Karo structural analysis can be seen in Table 3 and Fig. 9. 
Table 3. Recapitulation of Batak Karo structural analysis.

\begin{tabular}{cccc} 
Structural & $\begin{array}{c}\text { Structural } \\
\text { stress } \\
\text { Analysis } \\
\text { SAP2000 } \\
(\mathrm{MPa})\end{array}$ & $\begin{array}{c}\text { Allowable } \\
\text { stress } \\
(\mathrm{MPa})\end{array}$ & Explanation \\
\hline $\begin{array}{c}\text { Axial Force } \\
\text { Flexural } \\
\text { strength }\end{array}$ & 6,952 & 71,96 & Safe \\
\hline
\end{tabular}

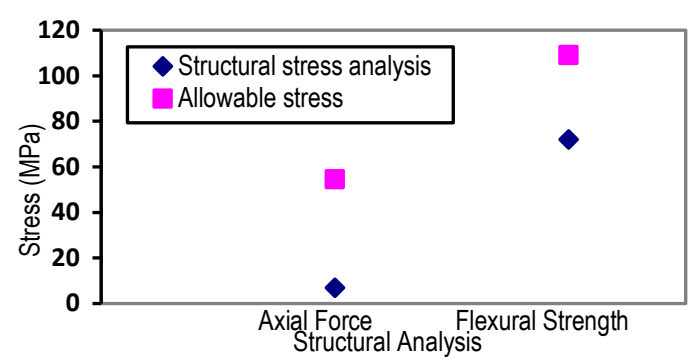

Figure 9. Structural analysis of Batak Karo house.

\section{Conclusions}

From this research, some conclusions can be drawn as follows:

The modeling results show that the deformation that in all poles still suitable for restrictions factored load combinations and load regulation based on earthquake in Indonesia. The results of the calculations show that the compressive strength of the tension that occurs at the pole is still samller than the compressive strength of wood $(\mathrm{Fc})$ so that the mast is still in strong condition.

The results show that the bending strength calculation of the tension occurs in both of beam is still less than the bending strength of wood $(\mathrm{Fb})$ so that the beam still in strong condition. The foundation system in Karo wooden house using stones to hold the ground shaking. It is the form of the joints, allowing the pole can hold the force due to earthquake loads and lateral loads. In general it can be concluded that due to the earthquake load and lateral load custom the structure of Karo House is in a safe condition.

\section{Acknowledgements}

The authors gratefully for Indonesian Ministry of Education Directorate General of Higher Education (DIKTI) through International Research Collaboration and Scientific Publication scheme on 2015-2017 and Universitas Islam Indonesia. We also gratefully for F. Dona Artha, Aristya Wiracitra, Dhicha P. Maharani, Harum I. Mahadma and Dwi Rosida to all of information in this research.

\section{References}

ANSS Composite Catalog Search. 19 August 2015. http://www.quake.geo.berkeley.edu/anss/catalogsearch.html.

Mardikanto, TR; L. Karlinasari; and E.T. Bahtiar 2011. Sifat Mekanis Kayu. IPB Press, Kampus IPB Taman Kencana Bogor.

Nurdiah, E.A. 2011. Studi Struktur dan Konstruksi Rumah Tradisional Suku Batak Toba, Minangkabau dan Toraja. Universitas Kristen Petra. Surabaya.

Prihatmaji, Y.P. and Widodo. 2015. Study on Strctural Performance of Indonesian Wooden Building and Development of Retrofit Methods. Final Report International Research Collaboration and Scientific Publication, Yogyakarta, Indonesia.

Pudjisuryadi, P.; B. Lumantarna; and Y. Lase. 2007. Base Isolation in Wooden Building, Lesson Learned From from Nias March 28, 2005 Earthquake. International Conference EACEF 2007, Jakarta, Indonesia.

Puslitbang Teknologi Hasil Hutan (PTHH). 2005. Atlas Kayu Indonesia. Puslitbang Teknologi Hasil Hutan.

Satyarno, I.; P. Nawangalam; and R.I. Pratomo P. 2012. Belajar SAP2000 Analisis Gempa. Zamil Publishing, Yogyakarta.

SNI 03-1726-2002. 2002. Standar Perencanaan Ketahanan Gempa untuk Struktur Bangunan Gedung. Badan Standarisasi Nasional, Jakarta.

SNI 1726-2012. 2012. Tata Cara Perencanaan Ketahanan Gempa untuk Struktur Bangunan Gedung dan Non Gedung. Badan Standarisasi Nasional, Jakarta.

Sembiring, T.U.B. 2010. Bentuk dan Fungsi Ornamen Rumah Tradisional Karo di Desa Lingga sebagai Daya Tarik Wisata Budaya, Reprository USU.

Pranata, Y.A. and K. M. William. 2013. Sistem Base Isolation pada Rumah Kayu Tradisional Ammu Hawu, Pulau Sabu, Nusa Tenggara Timur. Sustainable Culture Architecture \& Nature 2013, Yogyakarta, Indonesia.

Khairussa'diah

Department of Civil Engineering,

Universitas Islam Indonesia

Jl. Kaliurang km. 14, Yogyakarta, 55584, Indonesia

Tel : :62-82-226-227-848

Email : khairussadiah@yahoo.co.id

Corresponding Author:

Yulianto P. Prihatmaji

Department of Architecture,

Sekolah Tukang Nusantara (SETON)

Universitas Islam Indonesia

Jl. Kaliurang km. 14, Yogyakarta, 55584, Indonesia

Tel : : +62274896440

Fax : +62274895330

Email : prihatmaj@uii.ac.id 